\title{
Laboratory investigation of monoclonal gammopathy during 10 years of screening in a general hospital
}

\author{
VITTORE MALACRIDA, DANIELA DE FRANCESCO, G BANFI, F A PORTA,* \\ PAMELA G RICHES $\dagger$ \\ From the Laboratorio Di Patologica Clinica, Ospedale Di Busto Arsizio, Lombardia, the *Clinica Pediatrica, \\ Universita Di Pavia, Pavia, Italy, and the $†$ School of Allied Health Professions, University of Wisconsin, \\ Madison, United States of America
}

SUMMARY Protein electrophoresis was carried out on 102000 samples from the patients of a district general hospital over 10 years, and a monoclonal protein was detected in 730 cases; of these, 114 could be classified as B cell malignancies and 261 as monoclonal gammopathy of undefined significance (MGUS). The various clinical and laboratory features of monoclonal gammopathy were examined with respect to distinguishing the malignant conditions from MGUS at first presentation.

Monoclonal immunoglobulin is the product of an expanded clone of $B$ cells and is characteristically detected as a discrete band, or paraprotein, by electrophoresis of the serum or urine. The clone of cells producing the paraprotein can result from either a benign or malignant proliferation of B lymphocytes.

The patient whose monoclonal immunoglobulin is associated with overt B cell malignancy can usually be identified by a combination of clinical and laboratory findings. In the diagnosis of benign paraproteinaemia a temporal stability is implicit. In the time before follow up data become available the presence of a monoclonal protein in the absence of associated pathology has been defined as monoclonal gammopathy of undefined significance (MGUS). ${ }^{1}$

The humoral characteristics of MGUS are represented by a low concentration of monoclonal protein, ${ }^{23}$ undetectable Bence-Jones protein, ${ }^{2}$ normal bone marrow plasma cell morphology at less than $10 \%{ }^{4}$ and normal concentrations of albumin ${ }^{4}$ haemoglobin, ${ }^{5}$ and polyclonal immunoglobulin. ${ }^{4}$

Screening of general populations or blood donors shows that benign paraproteinaemia predominates, suggesting that only a small proportion of cases progress to frank malignancy. In hospital patients who represent a more selected population a higher incidence of malignancy is associated with the chance finding of a paraprotein. ${ }^{6}$ As the laboratory in-

Accepted for publication 3 Feburary 1987 vestigation of many hospital patients may include serum and urine electrophoresis, chance findings of monoclonal immunoglobulins in this group is clearly clinically important.

In the present study samples from a large hospital population were screened by electrophoresis and, whenever possible, patients with a monoclonal immunoglobulin were classified as having B cell malignancy or MGUS. Laboratory results were analysed with respect to the diagnosis at presentation of $B$ cell malignancy or MGUS, and also to the outcome of follow up studies on the group with MGUS.

\section{Patients and methods}

Serum samples were obtained from January 1973 to June 1983 from the patients of the Ospedale di Busto Arsizio, a district (provincial) general hospital serving an administration area of 137276 inhabitants and an undefined number of outpatients from surrounding areas. Age and sex specific incidence rates were calculated from 1982 census data for Busto Arsizio's population.

Serum was examined by protein electrophoresis on cellulose acetate membranes in a Sepratek cell (Gelman Instrument Company, Ann Arbor, Michigan, USA). Monoclonal protein concentrations were estimated by densitometry using a Seroprint Elvi 20 scanner (Milan, Italy) or an 807 Saitron scanner (Florence, Italy). Urine was concentrated 50 to 100 times before analysis by electrophoresis. Total protein was estimated on unconcentrated urine.

Monoclonal proteins were identified by 
immunoelectrophoresis $^{7}$ using specific antisera (Kallestad, Maine, USA). Polyclonal immunogobulins were estimated by radial immunodiffusion and, from 1980, by laser nephelometry (Hyland Laboratories, Costa Messa, California, USA).

\section{Results}

Seven hundred and thirty cases of paraproteinaemia were identified from screening 102000 serum samples by protein electrophoresis: in 195 of these the paraprotein concentration was less than $2 \mathrm{~g} / 1$, which could be seen by visual inspection but was not distinguishable by densitometry or identifiable by immunoelectrophoresis; in a further 160 samples there were incomplete laboratory or clinical data. Of the remaining 375 cases, 114 were classified as B lymphocyte malignancies (multiple myeloma $\mathrm{n}=96$, Waldenstrom's macroglobulinaemia $n=4$, chronic lymphatic leukaemia $\mathrm{n}=8$, non-Hodgkin's lymphoma $\mathrm{n}=6$ ), and 261 as MGUS.

Table 1 shows the distribution of paraprotein concentrations in MGUS. The median value in MGUS was $14.1 \mathrm{~g} / 1$ while in myeloma it was $32.5 \mathrm{~g} / \mathrm{l}$. An initial concentration of paraprotein greater than $30 \mathrm{~g} / 1$ was seen in only four patients classified as having MGUS.

The distribution of heavy chain classes of the paraprotein in 96 patients classified as having myeloma was as expected, with $60 \% \mathrm{IgG}, 25 \% \mathrm{IgA}, 1 \%$ each IgM, IgD, and biclonal, and $11 \%$ Bence-Jones protein. The $\kappa: \lambda$ ratio of $I g G$ paraproteins was 2.23 and that of $\operatorname{IgA} 1 \cdot 77$. Table 2 shows the distribution in MGUS.

A suppression of polyclonal immunoglobulin concentration - that is, one or more non-paraprotein immunoglobulin values below the lower limit of the reference range, was seen in $11.8 \%$ of patients with MGUS and $96 \%$ of those with myeloma. In MGUS this suppression was not related to organ disease but rather to age (table 3). The incidence increased with age, and the overall incidence was greater in men (154:107). Over the age of 75 years the male:female ratio of the patients with MGUS was 1.0 , but in the population as a whole in this age group, women outnumber men by $2 \cdot 5: 1$. Therefore, when the incidence
Table 2 Distribution of heavy chain class and light chain type of serum paraprotein in 261 patients with MGUS

\begin{tabular}{lrrrrr}
\hline Heavy chain class & & \multicolumn{3}{l}{ Light chain type } \\
\cline { 5 - 6 } & No (\%) & & $\kappa$ & $\lambda$ & Unidentified \\
\hline IgG & $197(75 \cdot 50)$ & 106 & 89 & 2 \\
IgA & $32(12 \cdot 25)$ & 12 & 17 & 3 \\
IgM & $32(12 \cdot 25)$ & 6 & 2 & 24 \\
\hline
\end{tabular}

of MGUS is adjusted according to the population statistics the male prevalence becomes more apparent.

Bence-Jones protein was present in $57.2 \%$ of the patients with myeloma. The urines of 161 of the patients classified as having MGUS were investigated and Bence-Jones protein could be detected in 22 $(13.6 \%)$ of these. Table 3 shows the amount of BenceJones protein detected, together with the age dependent occurrence. Within the MGUS group with dectectable Bence-Jones protein there was a correlation between the amount of proteinuria $(x)$ and the paraprotein concentration (y); the equation for the regression line was $y=5.791+10.230 \mathrm{X}$, and linear regression analysis gave a correlation coefficient of 0.774 with a probability of less than 0.0001 . The presence or absence of Bence-Jones protein in the group as a whole, however, could not be determined from the paraprotein concentration.

Mean calcium concentration was $2.21 \mathrm{mmol} / \mathrm{l}$ in MGUS and $2.63 \mathrm{mmol} / \mathrm{l}$ in myeloma but bore no relation to stage of disease.

In all the patients with myeloma the bone marrow biopsy specimen showed more than $20 \%$ plasma cells, most often with abnormal morphology. In 64 patients with MGUS undergoing bone marrow biopsy the plasmacytosis was greater than $20 \%$ in only two cases, in both of which this would have been accounted for by disease (one carcinoma of the larynx and the other carcinoma of the stomach). In 15 cases the plasmacytosis exceeded $10 \%$ and in 13 was greater than $5 \%$. No marrow showed any abnormal morphological forms of plasma cells.

MGUS was associated with a large number of different pathologies, both malignant (other than B cell) $(20 \%)$ and non-malignant $(74 \%)$, and only $6 \%$ of patients were asymptomatic. In this malignant group the most prevalent tumours were of the lung

Table 1 Distribution of paraprotein concentrations in 261 patients with MGUS

\begin{tabular}{|c|c|c|c|c|c|c|c|c|c|c|c|}
\hline \multicolumn{12}{|c|}{ Paraprotein ( $g / l)$} \\
\hline & $\begin{array}{l}4 \cdot 3- \\
6 \cdot 3\end{array}$ & $\begin{array}{l}6 \cdot 4- \\
8 \cdot 3\end{array}$ & $\begin{array}{l}8 \cdot 4- \\
10 \cdot 3\end{array}$ & $\begin{array}{l}10 \cdot 4- \\
12 \cdot 3\end{array}$ & $\begin{array}{l}12 \cdot 4- \\
14 \cdot 3\end{array}$ & $\begin{array}{l}14 \cdot 4- \\
16 \cdot 3\end{array}$ & $\begin{array}{l}16.4- \\
18.3\end{array}$ & $\begin{array}{l}18.4- \\
20.3\end{array}$ & $\begin{array}{l}20 \cdot 4- \\
22 \cdot 3\end{array}$ & $\begin{array}{l}22 \cdot 4- \\
24 \cdot 3\end{array}$ & $>24.4$ \\
\hline $\begin{array}{l}\text { No of } \\
\text { patients }\end{array}$ & 4 & 18 & 36 & 42 & 42 & 26 & 22 & 28 & 16 & 15 & 12 \\
\hline
\end{tabular}


Table 3 Age and sex related incidence of MGUS, together with immune suppression of non-paraprotein immunogobulin and occurrence and amount of Bence-Jones proteinuria

\begin{tabular}{|c|c|c|c|c|c|}
\hline \multirow[b]{2}{*}{ Age (years) } & \multicolumn{2}{|c|}{ No of patients } & \multirow{2}{*}{$\begin{array}{l}\text { Immune } \\
\text { suppression (\%) }\end{array}$} & \multirow{2}{*}{$\begin{array}{l}\text { No of patients }{ }^{*} \text { with } \\
\text { detectable Bence-Jones } \\
\text { protein }\end{array}$} & \multirow{2}{*}{$\begin{array}{l}\text { Amount of Bence-Jones } \\
\text { protein }(\mathrm{g} / \mathrm{l}) \\
\text { mean (range) }\end{array}$} \\
\hline & $M$ & $F$ & & & \\
\hline $\begin{array}{l}\text { Below } 50 \\
50-60 \\
60-70 \\
\text { Above } 70\end{array}$ & $\begin{array}{l}13 \\
17 \\
27 \\
50\end{array}$ & $\begin{array}{l}11 \\
27 \\
45 \\
71\end{array}$ & $\begin{array}{c}0 \\
9 \\
12 \cdot 9 \\
14.9\end{array}$ & $\begin{array}{r}0 \\
2 \\
4 \\
16\end{array}$ & $\begin{array}{l}-(0.7,1.0) \\
1.0(0.6-1.8) \\
0.9(0.4-2.0)\end{array}$ \\
\hline
\end{tabular}

*The urines of 161 of the 261 patients were investigated for the presence of Bence-Jones protein.

Table 4 Period of follow up study for patients with MGUS in whom Bence-Jones protein was detected at presentation, and those in whom the paraprotein concentration was greater than $20 \mathrm{~g} / \mathrm{l}$ at presentation

\begin{tabular}{llllll}
\hline & \multicolumn{2}{l}{ No of patients followed up (years) } & & \\
\cline { 2 - 5 } & 1 & 2 & 3 & 4 & 5 (or longer) \\
\hline $\begin{array}{l}\text { Bence-Jones protein } \\
(\mathrm{n}=22)\end{array}$ & 8 & 3 & 3 & 3 & 5 \\
$\begin{array}{l}\text { Paraprotein greater than } \\
20 \mathrm{~g} / \mathrm{l}(\mathrm{n}=25)\end{array}$ & 9 & 6 & 3 & 3 & 4 \\
\hline
\end{tabular}

(19.2\%), bladder $(15 \cdot 5 \%)$, stomach $(13.4 \%)$ with minor occurrences of other tumours. The most common non-malignant disease was of cardiovascular origin $(18.4 \%)$. Other conditions were mainly inflammatory (infection, arthropathy, autoimmune) or chronic.

Where possible, patients in the MGUS group had investigations repeated at least yearly. Only five patients progressed to frank malignancy, at times varying from 1 (P1) to 10 years (P5) after presentation.

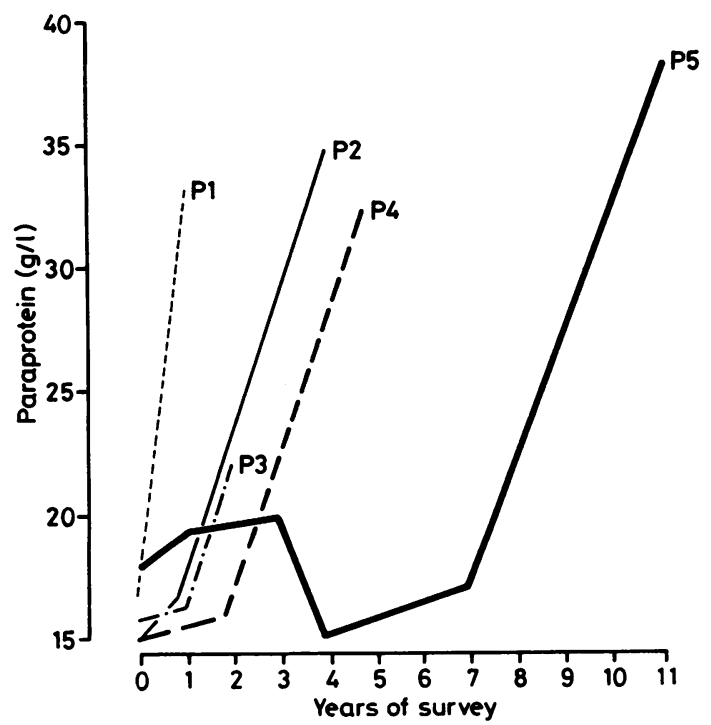

Figure Paraprotein concentration in five patients $(P 1, P 2$, P3, P4, and P5) followed for up to 11 years showing progression from MGUS to frank myeloma.
The figure shows the paraprotein concentrations in these five patients.

Follow up studies in a further 92 patients, initially diagnosed as having MGUS, indicated no progression to B cell malignancy during the time of the study; 75 for one to seven years, 13 for nine years, and three for 10 years. All 22 patients in whom BenceJones protein was detected were included in this group, as were 25 patients who had paraprotein concentrations between $20-30 \mathrm{~g} / 1$ at presentation: table 4 shows the number of years for which follow up data were available for patients in these two groups. Of the four patients with paraprotein concentrations greater than $30 \mathrm{~g} / \mathrm{l}$, one showed a $21 \%$ decrease after two years, and in the other three followed up for five, eight, and 10 years, respectively, the paraprotein concentration remained stable.

Of the total group of 92 patients with MGUS, 62 patients showed some variation in paraprotein concentration during the time of the study. The paraprotein was found to decrease in 17 cases, to be transient in four, and to increase in 41 , although these increases were neither progressive nor was there any other suggestion of evolution to B cell malignancy. The mean survival of the paraprotein in patients with transient MGUS was three months. There was no consistent pattern of associated disease in those patients who did not progress to B cell malignancy but who did show some variation in paraprotein concentrations (table 5).

\section{Discussion}

In agreement with many other workers an absolute 
Table 5 Follow up study of MGUS showing change in paraprotein concentration together with associated disease

\begin{tabular}{|c|c|}
\hline No of patients & Associated disease \\
\hline \multicolumn{2}{|l|}{ Decreased $(n=17)$} \\
\hline 3 & $\begin{array}{l}\text { Bacterial infection (1 urinary tract, } \\
2 \text { cholecystitis) }\end{array}$ \\
\hline 3 & $\begin{array}{l}\text { Autoimmune ( } 1 \text { connective tissue disease, } \\
2 \text { chronic active hepatitis) }\end{array}$ \\
\hline 2 & $\begin{array}{l}\text { Vascular ( } 1 \text { infarction, } 1 \text { subarachnoid } \\
\text { haemorrhage) }\end{array}$ \\
\hline 9 & $\begin{array}{l}\text { Acute pathology or chance finding on } \\
\text { electrophoresis }\end{array}$ \\
\hline \multicolumn{2}{|l|}{ Transient $(n=4)$} \\
\hline 1 & Coeliac disease \\
\hline$i$ & Thalassaemia with Staphylococcus infection \\
\hline 1 & Rubella \\
\hline 1 & Viral hepatitis \\
\hline \multicolumn{2}{|l|}{ Increased $(n=41)$} \\
\hline 10 & Cardiovascular disease \\
\hline 8 & Neoplasia \\
\hline 3 & Diabetes \\
\hline 2 & Lung diseases \\
\hline 18 & $\begin{array}{l}\text { Acute pathology or chance finding on } \\
\text { electrophoresis }\end{array}$ \\
\hline
\end{tabular}

cut off value of paraprotein cannot be used to distinguish MGUS from myeloma. If a concentration of $20 \mathrm{~g} / 1^{23}$ is taken as the cut off value then 29 patients in the present series showed concentrations greater than this, and even at a cut off value of $30 \mathrm{~g} / 1^{4}$ there were still four patients with higher concentrations. All patients who progressed to frank myeloma presented with paraprotein concentrations of less than $20 \mathrm{~g} / \mathrm{l}$.

Similarly the presence or absence of Bence-Jones protein in the urine does not absolutely distinguish MGUS from myeloma. ${ }^{89}$ The reported incidence of Bence-Jones protein in MGUS varies from $14 \cdot 1 \%^{10}$ to $26 \%{ }^{11}$ and finally $40 \%$ in the study of Lindstrom, who considers that Bence-Jones protein does not distinguish myeloma until the concentration is greater than $1 \mathrm{~g} / \mathrm{l}^{12}$

It was interesting that the concentration of paraprotein could not predict the presence of Bence-Jones protein, but in those patients with Bence-Jones protein the amount correlated with the paraprotein concentration. Age seemed to be the most important variable determining the presence of Bence-Jones protein. Therefore, it was in the elderly patient, with higher concentrations of paraprotein, in whom clinically important concentrations of Bence-Jones protein were found. Of the laboratory variables investigated in the present study, the presence of BenceJones protein was still the most specific in predicting malignancy, with a predictive value of $71 \%$ in the whole group and $90 \%$ in patients younger than 70 years of age.

A suppression of polyclonal immunoglobulin is a commonly observed feature of myeloma ${ }^{213}$ but has
Malacrida, de Francesco, Banfi, Porta, Riches $\stackrel{\bigcirc}{\overline{5}}$

also been reported in association with MGUS in $22 \cdot 3 \%,{ }^{14} 33 \%,{ }^{15} 38 \% \%^{116}$ and in $60 \%{ }^{12}$ of patients. The number of patients with MGUS and immune suppression shown in the present series $(11.8 \%)$ is somewhat lower than those previously published.

Increased numbers of plasma cells were seen in the bone marrow biopsy specimen of a number of patients with MGUS, but with no aberrant morphology. The finding of abnormal plasma cells is therefore a more important feature than absolute numbers, as was stated many years ago. ${ }^{17}$

MGUS prevailed in elderly patients and was more common in men than women when the incidence was adjusted according to population statistics.

In this study $6 \%$ of patients with MGUS were asymptomatic, which agrees with the $5-10 \%$ reported by Isobe. ${ }^{18}$ In other series the reported incidence has been much higher at $26 \%{ }^{1}$ and $37 \%,{ }^{19}$ which may simply reflect variations in patient populations.

The association of MGUS with neoplasia is a common finding 116182021 as with inflammatory conditions. ${ }^{18}$ This was also found in this series in which $20 \%$ of MGUS were associated with non-B cell neoplasia. The distribution of the different neoplasms was as expected from the reported prevalence in the general population in this region. ${ }^{22}$ The prevalence of the different types of tumours associated with MGUS was variable ${ }^{182123}$ but may have reflected the variation in populations.

As might be expected, most of the transient paraproteins in the present series were associated with acute viral or bacterial infections, more unusual was the finding in one patient with coeliac disease. An association of transient paraproteinaemia with coeliac disease has been noted previously. ${ }^{24}$

An important criterion of benign paraproteinaemia is that the paraprotein concentration should remain stable. In several patients with MGUS there was some increase in concentration, and these patients may have represented a group in the early stage of development of benign paraproteinaemia in which the B cell clone was still expanding before becoming stabalised.

The progression from apparent MGUS to frank malignancy in $5.4 \%$ of cases compares with the low rates previously reported, ${ }^{125}$ although a much higher rate of $19 \%$ has also been reported ${ }^{19}$; but again this variation may reflect differences in patient selection or population.

In conclusion, most of the laboratory investigations used to assess the clinical importance of $\stackrel{\oplus}{?}$ paraproteinaemia either alone or in combinations are unable to distinguish absolutely malignant conditions from MGUS, and it remains important to do follow up studies with regular reassessment of laboratory and clinical findings. 


\section{References}

1 Kyle RA. Monoclonal gammopathy of undetermined significance. Am J Med 1978;64:814-26.

2 Hobbs JR. Paraproteins, benign or malignant? $\mathrm{Br}$ Med $\mathrm{J}$ 1967;3:699-704.

3 Spiegelberg HL, Fiskin BF, Mills WJ, Getchell G. Essential monoclonal immunoglobulins. Am J Clin Pathol 1968;50:604.

4 Ritzmann S, Loukas D, Sakai H, Daniels J, Levin W. Idiopathic (asymptomatic) monoclonal gammopathies. Arch Intern Med 1975;135:95-106.

5 Kyle RA, Griepp PR. The laboratory investigation of monoclonal gammopathies. Mayo Clin Proc 1978;53:719-39.

6 Kohn J. Benign paraproteinaemias. J Clin Pathol 1975;28 (suppl 6):77-82.

7 Grabar P. Immunoelectrophoretic analysis. In: Ackroyd JF, ed. Immunological methods. Oxford: Blackwell Scientific Publications, 1964

8 Dammacco F, Wladenstrom J. Bence Jones proteinuria in benign monoclonal gammopathiews. Acta Med Scand 1968;184:403-9.

9 Kyle RA, Maldonado JE, Bayrd ED. Idiopathic Bence Jones proteinuria-a distinct entity? Am J Med 1973;55:222-6.

10 Pick A, Shoenfeld Y, Frohlichmann R, Weiss H, Vana D, Schreibman S. Plasma cell dyscrasia. Analysis of $\mathbf{4 2 3}$ patients. JAMA 1979;241:2275-8.

11 Reed M, McKenna RW, Bridges R, Parkin J, Frizzera G, Brunning RD. Morphologic manifestations of monoclonal gammopathies. Am J Clin Pathol 1981;76:8-23.

12 Lindstrom F, Dahlstrom U. Multiple myeloma or benign monoclonal gammopathy? A study of differential diagnostic criteria in 44 cases. Clin Immunol Immunopathol 1978;10:168-74.

13 Broder S, Humphrey R, Durm M, Blackman M, Meade B, Goldman C, Strober W, Waldmann T. Impaired synthesis of polyclonal (non-paraprotein) immunoglobulins by circulating lymphocytes from patients with multiple myeloma. $N$ Engl J Med 1975;293:887-92.
14 Adams RA, Smith L, Pickering PEC. The incidence of monoclonal proteins during 7 years of screening in a District General Hospital. Immunology 1984;51:451-4.

15 Carter A, Tatarsky I. The physiopathological significance of benign monoclonal gammopathy: a study of 64 cases. $\mathrm{Br} J$ Haematol 1980;46:565-74.

16 Peltonen S, Wasastjerna C, Wager O. Clinical features of patients with serum M components. Acta Med Scand 1978;203: 257-63.

17 Ferrata A, Storti E. Le malattie del sangu. Milan: Vallardi, 1958:1525.

18 Isobe $T$, Osserman E. Pathologic conditions associated with plasma cell dyscrasias: a study of 806 cases. Ann NY Acad Sci 1971;190:507-18.

19 Bonomo L, Dammacco F, Miglietta A. Gammapatie monoclonali non mielomatose (o benigne). Aggiornamento del medico 1982;2:345-9.

20 Abramson N, Shattil S. M-components. JAMA 1973;223:156-9.

21 Migliore PJ, Alexanian R. Monoclonal gammopathy in human neoplasia. Cancer 1968;21:1127-31.

22 Berrino F. Registro tumori de la regione Lombardia 1976-1977.

23 Williams RC, Bailly RC, Howe RB. Studies of "benign" serum M-components. Am J Med Sci 1969;257:275-93.

24 Pena AS, Nieuwkoop JV, Schuit HRC, et al. Transient paraproteinaemia in a patient with coeliac disease. Gut 1976; 17:735-9.

25 Axelsson U. An eleven-year follow up on 64 subjects with $M$ components. Acta Med Scand 1977;201:173-5.

Request for reprints to: Dr Pamela G Riches, School of Allied Health Professions, University of Wisconsin, 6110 Medical Sciences Center, 1300 University Avenue, Madison, Wisconsin 53706, USA. 